\title{
PEMANFAATAN EKSTRAK DAUN SAMBUNG NYAWA (Gynura Procumbens [Lour].Merr) SEBAGAI ANTIOKSIDAN PADA MINYAK KELAPA MENGGUNAKAN PELARUT METANOL
}

\section{THE UTILIZATION OF SAMBUNG NYAWA (Gynura Procumbens [Lour].Merr) LEAVES EXTRACT AS AN ANTIOXIDANT FOR COCONUT OIL BY USING METHANOL AS SOLVENT}

\author{
Mersi Suriani Sinaga, Putri Defriska Siagian, Rika Ariska \\ Departemen Teknik Kimia, Fakultas Teknik, Universitas Sumatera Utara \\ Jl. Almamater Kampus USU Medan 20155, Indonesia \\ Email: defriskasiagian28@gmail.com
}

\begin{abstract}
Abstrak
Daun Sambung Nyawa (Gynura Procumbens [Lour].Merr) telah digunakan sebagai obat tradisional. Daun Sambung Nyawa mengandung senyawa flavonoid, sebagai antioksidan alami. Penelitian ini bertujuan untuk menganalisis pengaruh penambahan ekstrak daun Sambung Nyawa sebagai antioksidan dan kemapuan untuk menjaga kualitas minyak kelapa. Tahap awal penelitian, dilakukan ekstraksi flavonoid dari daun Sambung Nyawa dengan rasio bahan baku dengan pelarut (b/v) dan suhu ekstraksi. Hasil ekstraksi dengan kadar flavonoid total tertinggi dicampurkan ke dalam minyak kelapa selama 3 hari, 6 hari, 9 hari, 12 hari, dan 15 hari. Analisis kadar flavonoid total dalam ekstrak daun Sambung Nyawa menggunakan spektrofotometri UV-Vis. Analisis pada minyak kelapa meliputi bilangan asam, iod, serta peroksida. Kadar flavonoid total tertinggi diperoleh sebesar 1,32 \% pada rasio bahan baku dan pelarut 1:10 (b/v) dengan suhu ekstraksi $55^{\circ} \mathrm{C}$. Bilangan asam terendah diperoleh sebesar $0,45 \%$, bilangan iod tertinggi diperoleh sebesar 7,90 g $\mathrm{I}_{2} / 100 \mathrm{~g}$, dan bilangan peroksida terendah diperoleh sebesar $4,40 \mathrm{mg} \mathrm{O} / 100 \mathrm{~g}$ untuk minyak kelapa dengan penambahan ekstrak daun Sambung Nyawa dan lama waktu penyimpanan minyak kelapa 3 hari.
\end{abstract}

Kata kunci: antioksidan, ekstraksi, flavonoid, minyak kelapa, sambung nyawa

\begin{abstract}
Sambung Nyawa leaves (Gynura Procumbens [Lour].Merr) have been used as a traditional medicine. Sambung Nyawa leaves contain flavonoid compounds, its functional as a natural antioxidant. The aim of this study was to analyze the effect of Sambung Nyawa leaves extract addition as an antioxidant and ability to preserve the quality of coconut oil. Firstly, flavonoids were extracted from Sambung Nyawa leaves with combination of raw material to solvent ratio $(\mathrm{w} / \mathrm{v})$ and extraction temperature. The extracts which gave the highest total flavonoids contents were mixed into the coconut oil for 3 days, 6 days, 9 days, 12 days, and 15 days. Total flavonoids contents of Sambung Nyawa leaves extracts were analyzed by UV-Vis spectrophotometry. The analyses for coconut oil were the value of acid, iod, and peroxide number. The results showed that the highest total flavonoids contents of $1,32 \%$ be obtained with raw material to solvent ratio of $1: 10(\mathrm{w} / \mathrm{v})$ and extraction temperature of $55^{\circ} \mathrm{C}$. The lowest acid number of $0.45 \%$, the highest iod number of $7.90 \mathrm{gr}$ $\mathrm{I}_{2} / 100 \mathrm{gr}$, and the lowest peroxide number of $4.40 \mathrm{mg} \mathrm{O} / 100 \mathrm{gr}$ be obtained with stored time of 3 days for coconut oil which mixed with the Sambung Nyawa leaves extracts.
\end{abstract}

Keywords : antioxidant, extraction, flavonoid, coconut oil, sambung nyawa

\section{Pendahuluan}

Keanekaragan hayati Indonesia sangat berpotensi dalam penemuan senyawa baru sebagai antioksidan. Antioksidan adalah suatu senyawa atau komponen kimia yang dalam kadar atau jumlah tertentu mampu menghambat atau memperlambat kerusakan akibat proses oksidasi [18]. Antioksidan dibagi menjadi dua jenis yaitu antioksidan alami dan sintetis, antioksidan sintetis seperti BHA (Butil Hidroksi Anisol) dan BHT (Butil Hidroksi Toulene) sangat efektif untuk menghambat minyak atau lemak agar tidak terjadi oksidasi. Tetapi penggunaan BHA dan BHT banyak menimbulkan kekhawatiran akan efek sampingnya [16]. Kekhawatiran akan efek samping antioksidan sintetis mendorong para ahli kimia untuk mencari antioksidan alami yang lebih aman. Antioksidan yang ada saat ini banyak diambil dari bahan nabati seperti buahbuahan, rempah-rempah, jamu, dan sayuran. Salah satunya adalah sambung nyawa. Sambung Nyawa merupakan tanaman perdu yang berasal dari keluarga Asteraceae yang mengandung 
triterpenoid, polifenol, saponin, steroid, asam klorogenat, asam kafeat, asam vanilat, asam kumarat, asam para hidroksi benzoat, flavonoid, dan minyak atsiri [15]. Sambung Nyawa dikenal sebagai obat tradisional, misalnya: pengobatan demam, ruam, penyakit ginjal, migrain, sembelit, hipertensi, diabetes mellitus, dan kanker. Baru-baru ini, penelitian farmakologi melaporkan bahwa Sambung Nyawa memiliki anti-Herpes simplex virus, anti-hiperglikemia, anti-hiperlipidemia, anti inflamasi, analgesik, dan sifat hipertensi darah yang diinduksi ulang [17].

Sebagai tanaman herbal, Sambung Nyawa tidak tahan terhadap suhu tinggi. Cara untuk mendapatkan flavonoid yang terkandung di dalam Sambung Nyawa salah satunya dengan metode ekstraksi refluks, yakni ekstraksi dengan pelarut pada temperatur titik didihnya, selama waktu tertentu dan jumlah pelarutnya terbatas dan relatif konstan dengan adanya pendingin balik [19]. Efisiensi metode refluks dapat ditentukan oleh beberapa faktor, seperti ukuran partikel, kecepatan pengadukan, rasio bahan baku dan pelarut (b/v), waktu ekstraksi, suhu ekstraksi, dan jenis pelarut [13]. Pelarut yang digunakan adalah metanol, etanol, etil asetat, aseton, dan air [5].

Atas dasar pemikiran yang telah dipaparkan, maka pada penelitian ini dilakukan dengan metode refluks menggunakan pelarut metanol dengan memvariasikan rasio bahan baku dan pelarut dan suhu ekstraksi untuk memperoleh kadar flavonoid total. Selanjutnya kadar flavonoid total tertinggi digunakan sebagai antioksidan pada minyak kelapa berdasarkan analisis bilangan asam, iod, dan peroksida.

\section{Teori}

Sambung Nyawa merupakan tanaman herbal yang termasuk famili Compositae, merupakan tanaman menahun. Tanaman ini tingginya mencapai 3 meter atau lebih, batangnya bersegi agak lunak dan berair. Helaian daun berwarna hijau muda dengan bentuk bulat telur. Panjang daun sampai $6 \mathrm{~cm}$ dan lebar 3,5 cm. Ujung daun runcing, pangkal daun membulat, pinggir daun bergerigi dangkal, tangkai daun $1,5 \mathrm{~cm}$ atau lebih. Kedua permukaan daun berambut halus dengan pertulangan menyirip [1]. Klasifikasi Sambung Nyawa dalam dunia tumbuhan dapat dilihat pada Tabel 1. berikut :
Tabel 1. Klasifikasi Sambung Nyawa [2]

\begin{tabular}{|l|l|}
\hline \multicolumn{1}{|c|}{ Kingdom } & \multicolumn{1}{c|}{ Plantae } \\
\hline Divisio & Spermatophyta \\
\hline Subdivisio & Angiospermae \\
\hline Class & Dicotyledoneae \\
\hline Ordo & Asterales \\
\hline Familia & Asteraceae \\
\hline Genus & Gynura \\
\hline Species & $\begin{array}{l}\text { (Gynura Procumbens } \\
\text { [Lour].Merr) }\end{array}$ \\
\hline
\end{tabular}

Flavonoid merupakan fitokimia polyphenolic dengan struktur fenolik yang konsisten. Flavonoid terdiri dari flavon, flavanon, flavanols, flavanol dan flavanonols yang merupakan kelompok besar metabolit sekunder pada tanaman [10]. Flavonoid mengandung 15 atom karbon dalam inti dasarnya, yang tersusun dalam konfigurasi $\mathrm{C}_{6^{-}}$ $\mathrm{C}_{3}-\mathrm{C}_{6}$ yaitu dua cincin aromatik yang dihubungkan oleh satuan tiga karbon yang dapat atau tidak dapat membentuk cincin ketiga [12].

Senyawa antioksidan alami tumbuhan umumnya adalah senyawa fenolik atau polifenolik yang dapat berupa golongan flavonoid, turunan asam sinamat, kumarin, tokoferol, dan asam-asam organik polifungsional [4]. Antioksidan berfungsi untuk meredam aktivitas radikal bebas. Antioksidan adalah senyawa yang dapat mendonorkan elektronnya (pemberi atom hidrogen) kepada radikal bebas, sehingga menghentikan reaksi berantai, dan mengubah radikal bebas menjadi bentuk yang stabil. Antioksidan pada makanan digunakan untuk mencegah atau menghambat proses oksidasi yang terjadi pada produk makanan misalnya lemak, terutama yang mengandung asam lemak tidak jenuh, dapat teroksidasi sehingga menjadi tengik [7].

Mekanisme kerja antioksidan memiliki dua fungsi, yaitu sebagai pemberi atom hidrogen dan memperlambat laju autooksidasi dengan berbagai mekanisme diluar mekanisme pemutusan rantai autooksidasi dengan pengubahan radikal lipida ke bentuk lebih stabil [6].

Reaksi berantai pada radikal bebas (tanpa ada antioksidan) terdiri dari tiga tahap, yaitu [7]: Tahap inisiasi : $\mathrm{RH} \rightarrow \mathrm{R}^{*}+\mathrm{H}^{*}$

Tahap propagasi : $\mathrm{R}^{*}+\mathrm{O}_{2} \rightarrow \mathrm{ROO}^{*}$ $\mathrm{ROO}^{*}+\mathrm{RH} \rightarrow \mathrm{ROOH}+\mathrm{R}^{*}$

Tahap terminasi : $\mathrm{R}^{*}+\mathrm{R}^{*} \rightarrow \mathrm{R}-\mathrm{R}$ $\mathrm{ROO}^{*}+\mathrm{R} * \rightarrow \mathrm{ROOR}$ $\mathrm{ROO}^{*}+\mathrm{ROO}^{*} \rightarrow \mathrm{ROOR}+\mathrm{O}_{2}$

Dengan adanya antioksidan, antioksidan memberikan atom hidrogen atau elektron pada radikal bebas $\left(\mathrm{R}^{*}, \mathrm{ROO} *\right)$, mengubahnya ke 
bentuk yang lebih stabil, reaksi tersebut terdiri dari dua tahap, yaitu [8]:

$\begin{array}{ll}\text { Inisiasi } & : \mathrm{R}^{*}+\mathrm{AH} \rightarrow \mathrm{RH}+\mathrm{A}^{*} \\ & \text { Radikal lipida }\end{array}$

Propagasi $: \mathrm{ROO}^{*}+\mathrm{AH} \rightarrow \mathrm{ROOH}+\mathrm{A}^{*}$ Pengujian sifat kimia minyak kelapa dilakukan berdasarkan Standar Nasional Indonesia (SNI) - Minyak Kelapa 01-2902-1992 dapat dilihat pada Tabel 2.

Tabel 2. Standar Mutu Minyak Kelapa [20]

\begin{tabular}{|l|l|}
\hline \multicolumn{1}{|c|}{ Karakteristik } & \multicolumn{1}{|c|}{$\begin{array}{c}\text { Syarat Mutu } \\
\text { (Standar) } \\
\text { (SNI 01-2902- } \\
\text { 1992) }\end{array}$} \\
\hline Kadar air (\%) & Maksimal 0,5 \\
\hline Kadar kotoran (\%) & Maksimal 0,05 \\
\hline Bilangan Iod (g I $/ 100 \mathrm{~g})$ & $8-10$ \\
\hline $\begin{array}{l}\text { Bilangan Peroksida (mg } \\
\left.\mathrm{O}_{2} / 100 \mathrm{~g}\right)\end{array}$ & Maksimal 5 \\
\hline $\begin{array}{l}\text { Bilangan Asam (dihitung } \\
\text { sebagai asam laurat) }(\%)\end{array}$ & Maksimal 5 \\
\hline $\begin{array}{l}\text { Bilangan Penyabunan }(\mathrm{mg} \\
\text { KOH/g) }\end{array}$ & $255-265$ \\
\hline Warna, bau, dan aroma & Normal \\
\hline
\end{tabular}

\section{Metodologi Penelitian}

\section{Bahan Baku dan Peralatan}

Bahan baku utama dalam penelitian ini adalah serbuk daun Sambung Nyawa dan metanol. Peralatan yang digunakan pada penelitian ini adalah hot plate, ayakan 40 mesh, corong, refluks kondensor, labu leher tiga, blender, timbangan elektrik, termometer kertas saring, rotary evaporator, water bath, spektrofotometri UV-Vis, dan peralatan gelas.

\section{Prosedur Pembuatan Serbuk Daun Sambung Nyawa}

Sampel daun Sambung Nyawa dicuci bersih. Kemudian sampel dikeringkan dengan cara diangin-anginkan. Setelah kering, sampel dihaluskan menggunakan blender. Kemudian sampel diayak menggunakan ayakan 40 mesh hingga diperoleh serbuk daun sambung nyawa.

\section{Prosedur Ekstraksi Serbuk Daun Sambung Nyawa \\ Serbuk daun Sambung Nyawa} dimasukkan sebanyak $25 \mathrm{~g}$ ke dalam labu leher tiga. Kemudian Pelarut metanol digunakan untuk proses ekstraksi dimasukkan ke dalam labu leher tiga dengan perbandingan rasio bahan baku dan pelarut adalah 1:5 (b/v); 1:10 (b/v); dan 1:15 (b/v). Serbuk daun Sambung Nyawa diekstraksi dengan peralatan refluks selama 3 jam dengan kecepatan pengadukan $300 \mathrm{rpm}$ pada suhu ekstraksi $35^{\circ} \mathrm{C}, 45^{\circ} \mathrm{C}, 55^{\circ} \mathrm{C}$, dan 65 ${ }^{\circ} \mathrm{C}$. Setelah ekstraksi selesai hasil ekstraksi dipisahkan dari pelarutnya menggunakan alat rotary evaporator. Kemudian ekstrak dipekatkan dengan water bath pada suhu $50{ }^{\circ} \mathrm{C}$ hingga diperoleh ekstrak kental.

\section{Prosedur Pembuatan Minyak Kelapa}

Santan kental dari kelapa tua disiapkan sebanyak 4 L. Santan dimasak dengan api sedang selama \pm 5 jam. Minyak kelapa yang diperoleh, kemudian dipisahkan dengan kotorannya.

\section{Prosedur Pemanfaatan Ekstrak Metanol Daun Sambung NyawaSebagai Antioksidan pada Minyak Kelapa}

Minyak kelapa ditimbang sebanyak $15 \mathrm{~g}$. Ekstrak serbuk daun Sambung Nyawa diambil sebanyak 5\% dari jumlah minyak kelapa dan dikontakkan dengan minyak kelapa. Campuran disimpan sesuai variasi waktu penyimpanan selama 3 hari, 6 hari, 9 hari, 12 hari, dan 15 hari. Campuran dianalisis bilangan asam, bilangan peroksida, dan bilangan iodnya.

\section{Hasil dan Pembahasan \\ Pengaruh Rasio Bahan Baku dan Pelarut dan Suhu Ekstraksi Terhadap Kadar Flavonoid Total}

Hubungan pengaruh rasio bahan baku dan pelarut (b/v) dan suhu ekstraksi terhadap kadar flavonoid total dapat dilihat pada Gambar 1.

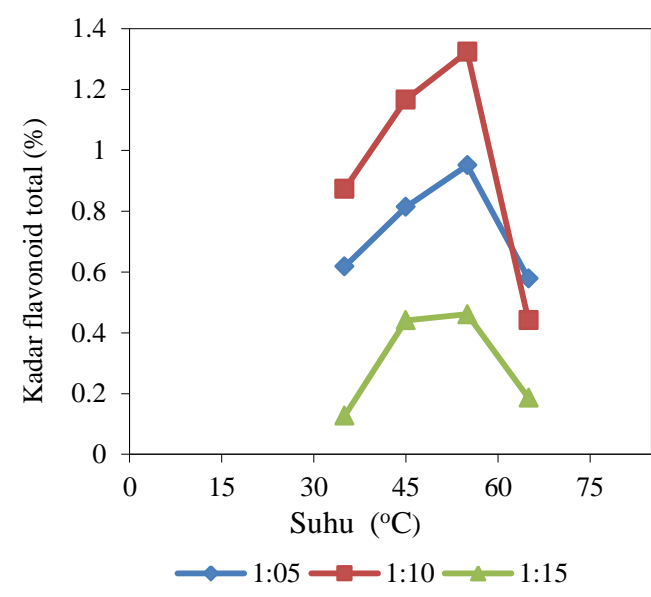

Gambar 1. Pengaruh Rasio Bahan Baku dan Pelarut dan Suhu Ekstraksi Terhadap Kadar Flavonoid Total

Gambar 1 menunjukkan grafik pengaruh rasio bahan baku dan pelarut sebesar 1:5 (b/v); $1: 10 \quad(\mathrm{~b} / \mathrm{v}) ; 1: 15 \quad(\mathrm{~b} / \mathrm{v})$ dan suhu ekstraksi terhadap kadar flavonoid total yang dihasilkan mengalami peningkatan pada suhu $35-55{ }^{\circ} \mathrm{C}$, namun kadar flavonoid total pada suhu ekstraksi 55-65 ${ }^{\circ} \mathrm{C}$ mengalami penurunan. Secara umum, 
semakin tinggi suhu ekstraksi padat-cair dan rasio bahan baku dan pelarut (b/v), maka semakin besar kadar flavonoid total yang diperoleh [3]. Peningkatan suhu menyebabkan pelarut semakin mudah melarutkan flavonoid dan membawanya keluar dari dalam/permukaan padatan daun sambung nyawa, sehingga meningkatkan difusitas pelarut dan meningkatkan kadar flavonoid total. Sedangkan, pengaruh rasio pelarut terhadap kadar flavonoid total ialah semakin besar rasio bahan baku dan pelarut maka semakin tinggi yield flavonoid yang diperoleh [14].

Menurut Tan dan Ho (2013) suhu proses ekstraksi berpengaruh dengan yield flavonoid pada tanaman henna. Pada suhu ekstraksi 25-55 ${ }^{\circ} \mathrm{C}$ dengan pelarut metanol, yield flavonoid yang diperoleh semakin meningkat. Hasil penelitian menyebutkan bahwa semakin besar suhu operasi ekstraksi, konsentrasi pelarut, dan waktu ekstraksi maka semakin besar flavonoid yang dihasilkan [21]. Sedangkan, menurut Weirong (2010), kondisi ekstrasi pada rasio bahan baku dan pelarut sebesar 1:5 (b/v), 1:10 (b/v), 1:15 $(\mathrm{b} / \mathrm{v}), 1: 20(\mathrm{~b} / \mathrm{v})$, dan $1: 25(\mathrm{~b} / \mathrm{v})$ dan variasi suhu ekstraksi sebesar $60{ }^{\circ} \mathrm{C}, 70{ }^{\circ} \mathrm{C}, 80{ }^{\circ} \mathrm{C}$, dan $90{ }^{\circ} \mathrm{C}$ dengan pelarut etanol menunjukkan semakin meningkat suhu operasi ekstraksi, konsentrasi pelarut, waktu ekstraksi, dan rasio bahan baku dan pelarut, maka semakin besar pula yield flavonoid tanaman Opuntia milpa alta [3].

Peningkatan suhu ekstraksi hingga $55{ }^{\circ} \mathrm{C}$ memberikan peningkatan kadar flavonoid total. Namun, peningkatan suhu ekstraksi hingga 65 ${ }^{\circ} \mathrm{C}$ tidak lagi memberikan peningkatan yang signifikan, melainkan mengalami penurunan signifikan. Hal ini disebabkan suhu yang terlalu tinggi menyebabkan kerusakan pada bahan yang sedang diproses. Jadi suhu terbaik pada penelitian ini ialah $55^{\circ} \mathrm{C}$.

Peningkatan rasio bahan baku dan pelarut hingga 1:10 memberikan peningkatan kadar flavonoid total tertinggi pada penelitian ini. Hal ini disebabkan karena rasio bahan baku (daun sambung nyawa) dan jumlah pelarutnya sudah cukup, sehingga pelarut dapat berpenetrasi dengan baik ke dalam bahan akibatnya flavonoid dapat dilarutkan oleh pelarut.

Pada penelitian ini menunjukkan kondisi suhu ekstraksi $55^{\circ} \mathrm{C}$ dan rasio bahan baku dan pelarut sebesar 1:10 dipilih sebagai kondisi paling baik untuk memberikan kadar flavonoid total yang tertinggi dibanding kondisi lainnya. Hasil analisis kadar flavonoid total penelitian ini diperoleh kadar flavonoid total ekstrak metanol daun Sambung Nyawa sebesar 1,32 \%.

\section{Pengawetan Minyak Kelapa}

Penelitian ini bertujuan untuk menganalisis pengaruh penambahan ekstrak daun Sambung Nyawa sebagai antioksidan dan lama waktu penyimpanan minyak kelapa terhadap bilangan asam, bilangan iod, dan bilangan peroksida. Ketiga parameter ini merupakan analisis yang sangat penting pada minyak kelapa untuk mengetahui kualitas minyak kelapa tersebut. Hasil analisis kadar flavonoid total tertinggi ekstrak metanol daun Sambung Nyawadiperoleh sebesar 1,32 \%.

Karakteristik minyak kelapa yang digunakan dalam penelitian ditunjukkan dalam Tabel 3.

Tabel 3. Karakteristik Minyak Kelapa

\begin{tabular}{|l|l|l|}
\hline \multicolumn{1}{|c|}{ Analisis } & \multicolumn{1}{c|}{$\begin{array}{c}\text { Hasil } \\
\text { Percobaan }\end{array}$} & $\begin{array}{c}\text { Syarat Mutu } \\
\text { (SNI 01-2902- } \\
\text { 1992) }\end{array}$ \\
\hline $\begin{array}{l}\text { Bilangan Asam } \\
(\%)\end{array}$ & 0,20 & Maksimal 5 \\
\hline $\begin{array}{l}\text { Bilangan Iod }(\mathrm{g} \\
\left.\mathrm{I}_{2} / 100 \mathrm{~g}\right)\end{array}$ & 8,38 & $8-10$ \\
\hline $\begin{array}{l}\text { Bilangan } \\
\text { Peroksida (mg } \\
\left.\mathrm{O}_{2} / 100 \mathrm{~g}\right)\end{array}$ & 4,00 & Maksimal 5 \\
\hline
\end{tabular}

Analisis Bilangan Asam pada Minyak Kelapa

Pengaruh dengan dan tanpa penambahan ekstrak daun Sambung Nyawa dan waktu penyimpanan terhadap perubahan bilangan asam pada minyak kelapa dapat dilihat pada Gambar 2.

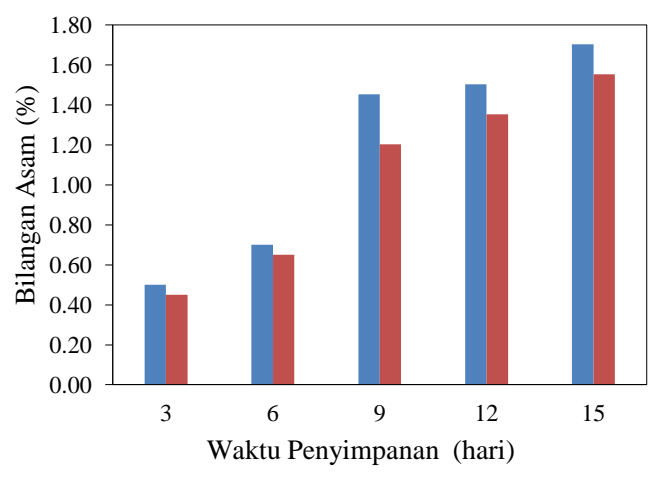

- Tanpa ekstrak sambung nyawa $₫$ Dengan ekstrak sambung nyawa

Gambar 2. Grafik Hasil Analisis Bilangan Asam pada Minyak Kelapa

Gambar 2 menunjukkan grafik pengaruh tanpa penambahan ekstrak daun Sambung Nyawa terhadap bilangan asam yang dihasilkan. Grafik ini menunjukkan bahwa bilangan asam semakin meningkat seiring bertambahnya waktu penyimpanan. Pada waktu penyimpanan minyak kelapa selama 3 hari, 6 hari, 9 hari, 12 hari, dan 15 hari diperoleh bilangan asam masing-masing 
sebesar $0,50 \% ; 0,71 \% ; 1,45 \% ; 1,50 \%$; dan $1,70 \%$. Sedangkan, grafik pengaruh penambahan ekstrak daun Sambung Nyawaterhadap bilangan asam selama 3 hari, 6 hari, 9 hari, 12 hari, dan 15 hari menghasilkan bilangan asam masing-masing sebesar 0,45 \%; $0,65 \% ; 1,20 \% ; 1,35 \%$; dan $1,55 \%$.

Berdasarkan hasil penelitian tentang pemanfaatan flavonoid ekstrak daun katuk sebagai antioksidan pada minyak kelapa yang dilakukan oleh Cikita (2015) menunjukkan bahwa pengaruh tanpa penambahan dan dengan penambahan ekstrak daun katuk menyebabkan bilangan asam semakin meningkat seiring bertambahnya waktu penyimpanan pada minyak kelapa dan semakin besar kadar flavonoid total yang digunakan maka semakin kecil bilangan asam yang diperoleh.

Hasil penelitian yang diperoleh telah sesuai dengan teori dimana pengaruh penambahan ekstrak daun Sambung Nyawa menyebabkan peningkatan bilangan asam lebih rendah bila dibandingkan dengan tanpa penambahan ekstrak daun sambung nyawa. Hal ini menunjukkan bahwa ekstrak daun Sambung Nyawa efektif sebagai antioksidan alami.

\section{Analisis Bilangan Iod Pada Minyak Kelapa}

Pengaruh penambahan dan tanpa penambahan ekstrak daun Sambung Nyawa dan waktu penyimpanan terhadap perubahan bilangan iod pada minyak kelapa dapat dilihat pada Gambar 3.

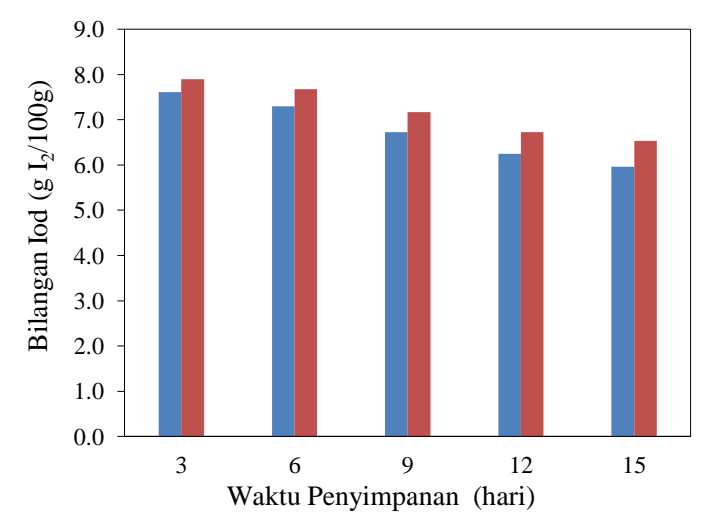

- Tanpa ekstrak sambung nyawa - Dengan ekstrak sambung nyawa

\section{Gambar 3. Grafik Hasil Analisis Bilangan Iod} pada Minyak Kelapa

Gambar 3 menunjukkan grafik pengaruh tanpa penambahan ekstrak daun Sambung Nyawa terhadap bilangan iod yang dihasilkan. Grafik ini menunjukkan bahwa bilangan iod semakin menurun seiring bertambahnya waktu penyimpanan. Pada waktu penyimpanan minyak kelapa selama 3 hari, 6 hari, 9 hari, 12 hari, dan 15 hari diperoleh bilangan iod masing-masing sebesar 7,61 $\mathrm{g} \mathrm{I}_{2} / 100 \mathrm{~g} ; 7,30 \mathrm{~g} \mathrm{I}_{2} / 100 \mathrm{~g} ; 6,73 \mathrm{~g}$ $\mathrm{I}_{2} / 100 \mathrm{~g} ; 6,25 \mathrm{~g} \mathrm{I}_{2} / 100 \mathrm{~g}$; dan 5,96 g I $/ 100 \mathrm{~g}$. Sedangkan, grafik pengaruh penambahan ekstrak daun Sambung Nyawa terhadap bilangan iod selama 3 hari, 6 hari, 9 hari, 12 hari, dan 15 hari menghasilkan bilangan iod masing-masing sebesar 7,90 $\mathrm{g} \mathrm{I}_{2} / 100 \mathrm{~g} ; 7,68 \mathrm{~g}$ $\mathrm{I}_{2} / 100 \mathrm{~g} ; 7,17 \mathrm{~g} \mathrm{I}_{2} / 100 \mathrm{~g} ; 6,73 \mathrm{~g} \mathrm{I}_{2} / 100 \mathrm{~g}$; dan $6,54 \mathrm{~g} \mathrm{I}_{2} / 100 \mathrm{~g}$.

Penurunan bilangan iod berhubungan dengan terbentuknya senyawa peroksida akibat oksidasi dan polimerisasi oksidasi yang terjadi. Hal ini terjadi karena ikatan rangkap pada asam lemak tidak jenuh semakin berkurang karena teradisi oleh atom oksigen membentuk peroksida. Dengan demikian, semakin tinggi bilangan peroksida minyak, maka bilangan iod semakin menurun. Penurunan bilangan iod ini juga disebabkan karena peristiwa polimerisasi asam lemak bebas dan asam lemak yang terikat pada trigliserida dimana ikatan rangkap terbuka untuk dapat bergabung dengan komponen asam lemak yang tidak jenuh lainnya [4]. Semakin tinggi angka iod, semakin bagus kualitas minyak [22].

Berdasarkan hasil penelitian tentang pemanfaatan flavonoid ekstrak daun katuk sebagai antioksidan pada minyak kelapa yang dilakukan oleh Cikita (2015) menunjukkan bahwa pengaruh tanpa penambahan dan dengan penambahan ekstrak daun katuk menyebabkan bilangan iod semakin menurun seiring bertambahnya waktu penyimpanan pada minyak kelapa dan semakin besar kadar flavonoid total yang digunakan maka semakin besar bilangan iod minyak kelapa yang diperoleh.

Hasil penelitian yang diperoleh telah sesuai dengan teori dimana pengaruh penambahan ekstrak daun Sambung Nyawa menyebabkan penurunan bilangan iod pada minyak kelapa. Hal ini menunjukkan bahwa ekstrak daun Sambung Nyawa efektif sebagai antioksidan alami.

\section{Analisis Bilangan Peroksida Pada Minyak Kelapa}

Pengaruh penambahan dan tanpa penambahan flavonoid total ekstrak daun Sambung Nyawa dan waktu penyimpanan terhadap perubahan bilangan peroksida pada minyak kelapa dapat dilihat pada Gambar 4. 


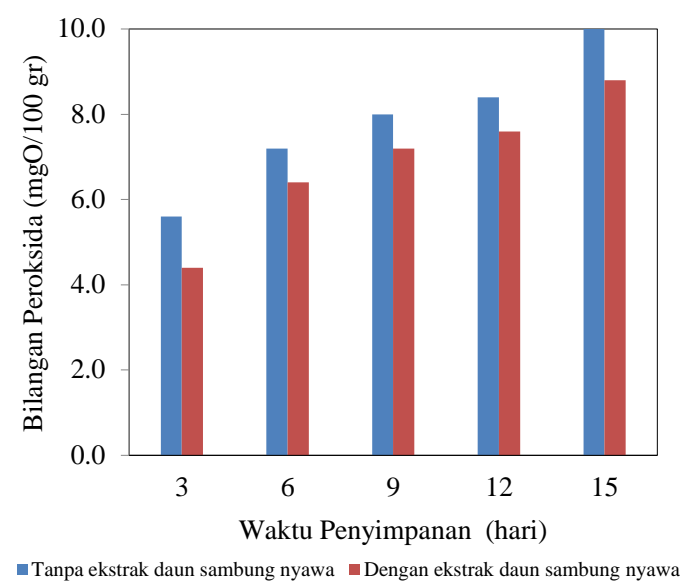

Gambar 4. Grafik Hasil Analisis Bilangan Peroksida pada Minyak Kelapa

Gambar 4 menunjukkan grafik pengaruh tanpa penambahan ekstrak daun Sambung Nyawa terhadap bilangan peroksida yang dihasilkan. Grafik ini menunjukkan bahwa bilangan peroksida semakin meningkat seiring bertambahnya waktu penyimpanan. Pada waktu penyimpanan minyak kelapa selama 3 hari, 6 hari, 9 hari, 12 hari, dan 15 hari diperoleh bilangan peroksida masing-masing sebesar $5,6 \mathrm{~g}$ $\mathrm{O}_{2} / 100 \mathrm{~g} ; 7,2 \mathrm{~g} \mathrm{O}_{2} / 100 \mathrm{~g} ; 8,0 \mathrm{~g} \mathrm{O}_{2} / 100 \mathrm{~g} ; 8,4 \mathrm{~g}$ $\mathrm{O}_{2} / 100 \mathrm{~g}$; dan $10,0 \mathrm{~g} \mathrm{O}_{2} / 100$ g. Sedangkan, grafik pengaruh penambahan ekstrak daun Sambung Nyawa terhadap bilangan peroksida selama 3 hari, 6 hari, 9 hari, 12 hari, dan 15 hari menghasilkan bilangan peroksida masingmasing sebesar 4,4 g O $\mathrm{g}_{2} / 100 \mathrm{~g} ; 6,4 \mathrm{~g} \mathrm{O}_{2} / 100 \mathrm{~g}$; 7,2 $\mathrm{g} \mathrm{O}_{2} / 100 \mathrm{~g} ; 7,6 \mathrm{~g} \mathrm{O}_{2} / 100 \mathrm{~g}$; dan $8,8 \mathrm{~g} \mathrm{O}_{2} / 100$ g. Bilangan peroksida menunjukkan ketengikan minyak akibat proses oksidasi dan hidrolisis. Pengukuran angka peroksida pada dasarnya adalah mengukur kadar peroksida dan hidroperoksida yang terbentuk pada tahap awal reaksi oksidasi lemak atau minyak. Bilangan peroksida yang tinggi mengindikasikan lemak atau minyak sudah mengalami oksidasi [9]. Bilangan peroksida semakin meningkat seiring dengan lama waktu penyimpanan minyak kelapa [11].

Berdasarkan hasil penelitian tentang pemanfaatan flavonoid ekstrak daun katuk sebagai antioksidan pada minyak kelapa yang dilakukan oleh Cikita (2015) menunjukkan bahwa pengaruh tanpa penambahan dan dengan penambahan ekstrak daun katuk menyebabkan bilangan peroksida semakin meningkat seiring bertambahnya waktu penyimpanan pada minyak kelapa dan semakin besar kadar flavonoid total yang digunakan maka semakin kecil bilangan peroksida minyak kelapa yang diperoleh.
Hasil penelitian yang diperoleh telah sesuai dengan teori dimana semakin besar kadar flavonoid total maka bilangan peroksida semakin menurun. Pengaruh penambahan ekstrak daun Sambung Nyawa menyebabkan peningkatan bilangan peroksida pada minyak kelapa seiring bertambahnya waktu penyimpanan. Hal ini menunjukkan bahwa ekstrak daun Sambung Nyawa efektif sebagai antioksidan alami.

\section{Kesimpulan}

1. Kadar flavonoid terbesar yang diperoleh sebesar 1,32 \% pada kondisi ekstraksi suhu $55^{\circ} \mathrm{C}$ dan rasio bahan baku dan pelarut $(\mathrm{b} / \mathrm{v})$ $1: 10$ serta waktu ekstraksi 2 jam.

2. Ekstrak daun Sambung Nyawa efektif sebagai antioksidan pada minyak kelapa. Hal dikarenakan ekstrak daun Sambung Nyawa memiliki kandungan flavonoid yang berfungsi sebagai antioksidan alami.

3. Semakin lama waktu penyimpanan minyak kelapa, maka bilangan asam dan bilangan peroksidanya akan semakin besar sedangkan bilangan iodnya akan semakin kecil.

4. Bilangan asam terendah yang diperoleh sebesar $0,45 \%$, bilangan iod tertinggi yang diperoleh sebesar 7,90 g $\mathrm{I}_{2} / 100 \mathrm{~g}$, dan bilangan peroksida terendah yang diperoleh sebesar 4,40 $\mathrm{mgO}_{2} / 100 \mathrm{~g}$ untuk minyak kelapa dengan penambahan antioksidan dan lama penyimpanan minyak kelapa 3 hari.

\section{Daftar Pustaka}

[1] Abdurrahman, Eko Kurniadi, Skripsi, Efek Ekstrak Daun Sambung Nyawa Terhadap Kualitas Sperma Tikus Diabetik Akibat Induksi Streptozotocin, Universitas Negeri Semarang, Semarang, 2007.

[2] Backer, C. A dan van Den Brink, R. C. B, Flora of Java, Jilid IIb. Penerbit Noordhoff, Neatherlands, p.425, 1965.

[3] Cai, Weirong., Xiaohong Gu., dan Jian Tang, Extraction, Purification, and Characterisation of the Flavonoid from Opuntia milpa alta Skin, Czech J.Food Sci.28, p.108-116, 2010.

[4] Cikita, Indah, Skripsi Pemanfaatan Flavonoid Total Dan Waktu Kontak Flavonoid Ekstrak Daun Katuk Sebagai Antioksidan Pada Minyak Kelapa, Universitas Sumatera Utara, Medan, 2015.

[5] Damanik, Desta Donna Putri., Nurhayati Surbakti., dan Rosdanelli Hasibuan, Ekstraksi Katekin Dari Daun Gambir (Uncaria gambir roxb) Dengan Metode Maserasi, Jurnal Teknik Kimia USU, 3 p.10-14, 2014. 
[6] Gordon MH, The Mechanism of antioxidant Activity In Vitro, Food Antioxidants, Elsevier Appl Sci, p.1-18, 1990

[7] Hamid, A.A., O.O.Aiyelaagbe., L.A.Usman., O.M.Ameen., dan A.Lawal, Antioxidants: Its medicinal and pharmacological Applications, African Journal of Pure and Applied Chemistry, 4, p.142-151, 2010.

[8] Inggrid, H Maria dan Herry Santoso, Ekstraksi Antioksidan dan Senyawa Aktif dari Buah Kiwi (Actinidia deliciosa), Lembaga Penelitian dan Pengabdian Kepada Masyarakat, Perjanjian No: III/LPPM/2014-03/10-P, 2014.

[9] Laitupa, Fahrurizal., Susane, H, Pemanfaatan Eugenol dari Minyak Cengkeh Untuk Mengatasi Ranciditas pada Minyak Kelapa, Universitas Diponegoro, 2010.

[10] Laghari, Abdul Qayoom., Shahabuddin Memon., Aisha Nelofar., and Abdul Hafeez Laghari, Extraction, Identification and Antioxide Properties Of The Flavonoid-Rich Fractions from Leaves and Flowers Of Cassia Angustifolia, American Journal Of Analytical Chemistry, 2, p.871-878, 2011.

[11] Madhavi. N., T. Deva Saroja, Chemical Constants of Some Edible Oils within The State of Andhra Pradesh, International Journal of Pharma and Bio Sciences, 5, p.437 - 440, 2014.

[12] Markham, K.R, "Techniques of Flavonoids Identification," diterjemahkan oleh Kosasih Padmawinata, Penerbit ITB, Bandung, 1988.

[13] Miryanti, Y.I.P Arry, Lanny Sapei, Kurniawan Budiono, dan Stephen Indra, Ekstraksi Antioksidan Dari Kulit Buah Manggis (Garcinia Mangostana L), Lembaga Penelitian dan Pengabdian Kepada Masyarakat. Universitas Katolik Parahyangan, 2011.

[14] Prasetyo, Susiana, Henny, Sunjaya, Yohanes Yanuar, Pengaruh Rasio Massa Daun Suji/Pelarut, Temperatur, dan Jenis Pelarut Pada Ekstraksi Klorofil Daun Suji Secara Batch Dengan Pengontakan Dispersi, Lembaga Penelitian dan Pengabdian Kepada Masyarakat, Perjanjian No:III/LPPM/2012-02/09-P, 2012.

[15] Priamsari, M.R, M. M. Susanti, A. Farmasi, T. Semarang, dan A. H. Atmaja, Pengaruh Metode Pengeringan Terhadap
Kualitas Ekstrak Dan Kadar Flavonoid Total Ekstrak Etanolik Daun Sambung Nyawa (Gynura Procumbens [Lour.] Merr.), Journal of Pharmacy, 5, p.2933, 2016

[16] R. Hermiati, N. Manalu, and M. Sinaga, Ekstrak Daun Sirih Hijau Dan Merah Sebagai Antioksidan Pada Minyak Kelapa, Jurnal Teknik Kimia USU, 2, p.37-43, 2012.

[17] Rosidah., Mun Fei Yam., Amirin Sadikun., dan Zaini Asmawi, Antioxidant Potential Of Gynura Procumbens, Journal Pharmaceutical Biology, 46, p. 616-625, 2008.

[18] Sayuti, Kesuma dan Rina Yenrina. Antioksidan, Alami dan Sintetik, Penerbit Andalas University Press, Sumatera Barat, p.7, 2015

[19] Setiaji, Guntur, Skripsi, Karakterisisasi dan Uji Aktivitas Antioksidan Minyak Hasil Ekstraksi Biji Honje, Universitas Islam Negeri Syarif Hidayatullah, Jakarta, 2014.

[20] Standar Nasional Indonesia (SNI), Minyak Kelapa Virgin, Badan Standarisasi Nasional, 1992

[21] Tan, M.C., Tan, C.P., and Ho.C.W, Effects of Extraction Solvent System, Time and Temperature On The Content Of Henna (Lawsonia inermis) Stems, International Food Research Journal, 20, p.3117 - 3123, 2013.

[22] Triyanto, A, Skripsi, Peningkatan Kualitas Minyak Goreng Bekas Menggunakan Arang Ampas Tebu Teraktivasi dan Penetralan dengan $\mathrm{NaHSO}_{3}$, Universitas Negeri Semarang, Semarang, 2013. 